Wilfrid Laurier University

Scholars Commons @ Laurier

$11-2015$

\title{
The Right to Food Under Hugo Chávez
}

Rhoda E. Howard-Hassmann

Wilfrid Laurier University, hassmann@wlu.ca

Follow this and additional works at: https://scholars.wlu.ca/poli_faculty

Part of the Political Science Commons

\section{Recommended Citation}

Howard-Hassmann, Rhoda E., "The Right to Food Under Hugo Chávez" (2015). Political Science Faculty Publications. 37.

https://scholars.wlu.ca/poli_faculty/37

This Article is brought to you for free and open access by the Political Science at Scholars Commons @ Laurier. It has been accepted for inclusion in Political Science Faculty Publications by an authorized administrator of Scholars Commons@ @aurier. For more information, please contact scholarscommons@wlu.ca. 


\section{PROJECT MUSE}

\section{The Right to Food Under Hugo Chávez}

Rhoda E. Howard-Hassmann

Human Rights Quarterly, Volume 37, Number 4, November 2015, pp. 1024-1045 (Article)

Published by Johns Hopkins University Press

DOI: $10.1353 / \mathrm{hrq} .2015 .0055$

$\Rightarrow$ For additional information about this article https://muse.jhu.edu/article/603225 


\title{
The Right to Food Under Hugo Chávez
}

\author{
Rhoda E. Howard-Hassmann*
}

\begin{abstract}
This article investigates the right to food in Venezuela under President Hugo Chávez (1999-2013). Although Chávez respected Venezuelans' right to food, he failed to protect it. In the short term, he fulfilled the right to food by establishing state-run stores where food was sold cheaply, and by imposing price controls. At the same time, he reduced the food supply by undermining property rights, expropriating large-scale ranches as well as wholesale and retail distributors. Violations of civil and political rights made it difficult for Chávez's critics to oppose his food policies. By the time Chávez died food shortages were extremely severe.
\end{abstract}

\section{THE HUMAN RIGHT TO FOOD}

This article discusses the right to food in Venezuela under Hugo Chávez. The 1948 Universal Declaration of Human Rights (UDHR) states that "[e] veryone has the right to a standard of living adequate for the health and well-being of himself and of his family, including food." ${ }^{11}$ Two international covenants codify the declared ideals of the UDHR into international law;

\footnotetext{
* Rhoda E. Howard-Hassmann is Canada Research Chair in International Human Rights at Wilfrid Laurier University and the Balsillie School of International Affairs. Her most recent books include Can Globalization Promote Human Rights? (2010) and her co-edited The Human Rights to Citizenship: A Slippery Concept (2015). She maintains a blog, Rights and Rightlessness, which can be accessed at http://rhodahassmann.blogspot.com. This article is part of her current research on state food crimes.

Dr. Howard-Hassmann thanks Antulio Rosales for his research assistance and comments for this article, as well as Javier Corrales, Francisco López-Bermudez, Kathryn Hochstetler, Ken Jackson, and Yehonatan Alsheh for their comments on earlier drafts. She also thanks the Canada Research Chairs program for the time and funds to write this article, and Wilfrid Laurier University for nominating her for her Chair.

1. Universal Declaration of Human Rights, adopted 10 Dec. 1948, G.A. Res. 217A (III), U.N. GAOR, 3d Sess, art. 25(1), U.N. Doc. A/RES/3/217A (1948).
} 
these are the International Covenant on Civil and Political Rights (ICCPR) ${ }^{2}$ and the International Covenant on Economic, Social and Cultural Rights (ICESCR). ${ }^{3}$ The ICESCR includes the rights to adequate food and freedom from hunger. ${ }^{4}$ Venezuela ratified both Covenants in 1978. Thus, it is bound by treaty to respect the human right to food.

There are three aspects of the right to food: to respect, protect, and fulfill it. ${ }^{5}$ President Hugo Chávez respected the right to food, attempted to fulfill it, but failed to protect it. His policies from 1999 to 2013 were originally intended to improve the access of the Venezuelan poor to food. He used Venezuela's oil wealth to establish food "missions" (misiones) that distributed free food to the poor, and set up state-owned markets (Mercals) that sold food in poverty-stricken areas at subsidized prices. ${ }^{6}$ He also imposed price controls on food. Thus, in the very short term he improved fulfillment of Venezuelans' right to food. During the later years of Chávez' tenure as president, however, he failed to protect the right to food: shortages became more and more common. Chávez' economic mismanagement suggested that if his policies were not remedied, food would become ever scarcer, as indeed it did under his successor, Nicolás Maduro.

\section{BACKGROUND}

From 1958 to 1998 Venezuela was ruled by an elite pact $^{7}$ that allowed the major political parties to alternate power and also accommodate the interests of minor political parties; while it was based particularly in the middle classes, the pact also accommodated the interests of other social groups such as organized labor, the church, business people, and the armed forces. ${ }^{8}$ The pact's economic basis lay in "clientelistic distribution of the petroleum income." ${ }^{\prime \prime}$

2. International Covenant on Civil and Political Rights, adopted 16 Dec. 1966, G.A. Res. 2200 (XXI), U.N. GAOR, 21st Sess., U.N. Doc. A/6316 (1966), 999 U.N.T.S. 171 (entered into force 23 Mar. 1976) [hereinafter ICCPR].

3. International Covenant on Economic, Social and Cultural Rights, adopted 16 Dec. 1966, G.A. Res. 2200 (XXI), U.N. GAOR, 21st Sess., U.N. Doc. A/6316 (1966), 993 U.N.T.S. 3 (entered into force 3 Jan. 1976).

4. Id. art. 11(1), (2).

5. Philip Alston \& Asbjørn Eide, Advancing the Right to Food in International Law, in FooD as a Human Right 160, 252-56 (Asbjorn Eide et al. eds., 1984).

6. Richard Gott, Hugo Chavez and the Bolivarian Revolution 239, 256-59 (2011); Bart Jones, Hugo! The Hugo Chavez Story from Mud Hut to Perpetual Revolution 394, 394-95 (2007).

7. Miriam Kornblith, Sowing Democracy in Venezuela: Advances and Challenges in a Time of Change, in State and Society in Conflict: Comparative Perspectives on Andean Crises 290, 290 (Paul W. Drake \& Eric Hershberg eds., 2006); Janet Kelly \& Pedro A. Palma, The Syndrome of Economic Decline and the Quest for Change, in The UnRAveling OF Representative Democracy in Venezuela 204, 204 (Jennifer L. McCoy \& David J. Myers eds., 2004).

8. Rafael Duarte Villa, Venezuela: Political Changes in the Chavez Era, 21 Estudos Avancados 153 (2007).

9. Id. at 154 . 
The pact encountered trouble in the 1980s and 1990s. In 1983, currency devaluation ushered in a period of social and economic decline in which poverty rates rose..$^{10}$ That same year witnessed an end to the "petro-bonanza," or the high price of oil that had started in 1973 and had permitted government elites to dispense benefits to their supporters. ${ }^{11}$ The period 1987 to 1998 was characterized by a drop in income per capita, a rise in inflation, currency depreciation, and a boom-and-bust economy that followed fluctuations in oil prices. ${ }^{12}$ In 1989, a shortage of basic foodstuffs, along with an increase in the price of gasoline, caused riots in Caracas, in which 300 to 1,000 people were killed. ${ }^{13}$ During the 1990s economic decline, increased unemployment and high rates of poverty continued. ${ }^{14}$ By 1998 between two thirds and three quarters of Venezuelans lived below the poverty line..$^{15}$ In 1999, the purchasing power of the average Venezuelan salary was only about 33 percent of what it had been in $1978 .{ }^{16}$

Thus, the Venezuelan economy was in a state of collapse before Chávez took power. Moreover, if Chávez mismanaged the economy and undermined long-term food security, his was certainly not the first Venezuelan government to do so. Below I discuss the detrimental effects of dual exchange rates and price controls on the food supply under Chávez' rule, but governments in the 1980s also instituted such policies. ${ }^{17}$ Chávez was not the first president to rely on oil rents to pay for government expenditures, rather than trying to encourage a more efficient economy. ${ }^{18}$

In 1992, Chávez, then a member of the military, attempted a coup d'état. The coup failed and he subsequently spent two years in jail; on his release, he established a mass political movement, the Movement of the Fifth Republic (referring to the Republic as it would become under his rule). In 1998, he successfully ran for president, receiving 58 percent of the vote. ${ }^{19}$ In 2002, Chávez defeated an attempted coup by middle-class and military elements. He won a recall referendum in 2004 and was re-elected president in 2006 and 2012. He died of cancer on 5 March 2013.

10. Kornblith, supra note 7, at 291.

11. David J. Myers, Venezuela: Delegative Democracy or Electoral Autocracy? in Constructing Democratic Governance in Latin America 285, 290 (Jorge I. Dominguez \& Michael Shifter, eds., 3d ed. 2008).

12. Kelly \& Palma, supra note 7, at 206-18.

13. Duarte Villa, supra note 8 , at 157.

14. Kornblith, supra note 7, at 298.

15. Myers, supra note 11, at 288; Michael Shifter, In Search of Hugo Chavez, 85 ForeigN Aff. 45, 47 (2006).

16. Kelly \& Palma, supra note 7 , at 207.

17. Roberto Briceno-Leon, Petroleum and Democracy in Venezuela, 84 Soc. Forces 1, 10 (2005).

18. Id. at $3-4$.

19. Duarte Villa, supra note 8 , at 160 . 
Many commentators consider Chávez to have been a populist leader. ${ }^{20}$ Populist political leaders appeal to the underprivileged masses; often this appeal relies on a perceived personal relationship between a charismatic leader and his followers rather than on an explicit policy platform. ${ }^{21}$ This appears to have been the case in Venezuela, where Chávez did not rely on an organized political party but rather on his own identification with the poor and his self-portrayal as a man of the masses, an identification made all the stronger because he was of non-European descent, as opposed to the white elite. ${ }^{22}$ Chávez also exemplified economic populism, relying on "the creation of a material base for the public's support and the distribution of favors to constituents," while ignoring resource constraints. ${ }^{23}$ But Chávez also relied on support from the military, from which he himself had emerged: ${ }^{24}$ members or former members of the military occupied many positions in government and the nationalized sectors of the economy. ${ }^{25}$

By the end of Chávez' tenure, the poor did not automatically support him, as many were fed up not only with food shortages but also with the corruption and nepotism that characterized his rule. Only in 1998 were the poor more likely to vote for Chávez than other income groups, though throughout his tenure the rich were disproportionately unlikely to vote for him. ${ }^{26}$ Chávez remained in power by a combination of genuine support from some of the poor, policies such as cheap gas and expanded state employment that benefited the middle classes as well as the poor, ${ }^{27}$ and a good dose of electoral chicanery. ${ }^{28}$ Chávez won every election in which he ran from 1998 to 2012, although he lost a 2007 referendum on constitutional amendments.

\section{THE RIGHT TO FOOD IN VENEZUELA}

Scholarly evaluations of Chávez' record as president are mixed; some focus on the good he did for Venezuela's poor while others emphasize the harm he caused to the economy. Those who praise him mention in particular his food policies. Chávez established the Mercals, or special people's markets,

20. Jorge G. Castañeda, Latin America's Left Turn. 85 Foreign Aff. 28, 38-42 (2006).

21. Richard Sandbrook, Mark Edelman, Patrick Heller, \& Judith Teichman, Social Democracy in the Global Periphery: Origins, Challenges, Prospects 28 (2007).

22. GotT, supra note 6 , at 239.

23. Ana Lucia Cordova Cazar \& Francisco Lopez-Bermudez, Latin American Populism, in Encyclopedia of Hum. Rts. Vol. 3, at 401 (David P. Forsythe, ed. 2009).

24. Kornblith, supra note 7 , at 311 .

25. Briceno-Leon, supra note 17 , at 19.

26. Noam Lupu Who Votes for Chavismo? Class Voting in Hugo Chavez's Venezuela, 45 Latin Am. Res. Rev. 7, 23 (2010).

27. Javier Corrales, Explaining Chavismo: The Unexpected Alliance of Radical Leftists and the Military in Venezuela under Hugo Chavez 32 (2010).

28. Javier Corrales, A Setback for Chavez, 22 J. Deмос 122 (2011). 
where a large range of subsidized goods could be purchased. By 2007, about 9.3 million people (out of a total population of about 28 million) shopped for food at the Mercals. ${ }^{29}$ The missions also distributed free, readyto-eat foods to the very poor. ${ }^{30}$ The free food was distributed to groups of neighborhood women who cooked hot lunches for the extremely poor in their own kitchens. ${ }^{31}$

By 2006 almost 16,000 stores throughout Venezuela offered subsidized food at about 27 to 39 percent less than market prices. ${ }^{32}$ Moreover, as of 2008, 3.9 million children benefited from a school food program, ${ }^{33}$ against only 252,000 children in 199934; children were given breakfast, lunch, and an afternoon snack. ${ }^{35}$ However, food shortages started to appear as early as 2007. Even two very pro-Chávez observers noted that "[i]n recent months there have been reports of shortages of foods such as beef, sugar, corn oil, milk, chicken and eggs." ${ }^{\prime \prime 6}$ By late 2007 other basic foodstuffs such as sardines and black beans were increasingly scarce. ${ }^{37}$

These shortages were caused by a combination of price controls and the rapid growth of consumption, along with some hoarding of goods. ${ }^{38}$ Food producers lacked incentives to produce and sell at control prices that were less than the cost of production. By 2008 a "steep drop in food production and widening food scarcity" resulted from price and exchange controls and threats to expropriate property by Chávez. These policies will be discussed below. ${ }^{39}$

Prices of non-controlled goods rose as producers tried to compensate for their losses on controlled goods, while demand for non-controlled goods rose as a reaction against shortages in the controlled sector. For example, some dairy producers substituted non-controlled cheese for controlled milk; one rice-processing plant started to sell non-controlled flavored rice. ${ }^{40}$ The sale of food at control prices also opened up opportunities to exploit the dual price system, as entrepreneurs could buy food at Mercals and then resell it,

29. Michael Penfold-Becerra, Clientelism and Social Funds: Evidence from Chavez's Missions, 49 Latin Am. Pol. \& Soc'y 63, 74 (2007).

30. Duarte Villa, supra note 8, at 166 .

31. JONES, supra note 6 , at 395.

32. Mark Weisbrot \& Luis Sandoval, The Venezuelan Economy in the Chavez Years, Center for Economic and Policy Research 2-3 (2007).

33. Mark Weisbrot, Poverty Reduction in Venezuela: A Reality-Based View, 8 ReVISTA: HarVard Rev. Latin Am. 1, 6 (2008).

34. Weisbrot \& Sandoval, supra note 32 , at 9.

35. Terry Gibbs, Business as Usual: What the Chavez Era Tells Us about Democracy under Globalisation 27 THIRD WORLD Q. 265, 274 (2006).

36. Weisbrot \& Sandoval, supra note 32 , at 17 .

37. Francisco Rodriguez, An Empty Revolution: the Unfulfilled Promises of Hugo Chávez, 87 Foreign AfF. 49, 56 (2008).

38. Weisbrot \& Sandoval, supra note 32 , at 16.

39. Rodriguez, supra note 37 , at 57.

40. Feeding Frenzy: Socialism in Venezuela, Economist, 14 Mar. 2009, at 40. 
illegally, at higher prices; or managers of Mercals could simply steal from inventory and sell the food at home or abroad. ${ }^{41}$ This method of exploiting the dual price system was especially lucrative because of the shortage of food at the Mercals. Prices of non-subsidized and non-controlled foods also rose drastically as a consequence of inflation, averaging about 22 percent annually from 2003 to $2011 .{ }^{42}$ In order to combat inflation, Chávez ordered controls on more and more items, so that by 2012 the prices of hundreds of staple foods were controlled. ${ }^{43}$

The more goods that were controlled, the higher the prices on the black, or informal, market became when goods could not be found at the Mercals. Thus, in a vicious spiral, price controls encouraged higher black market prices, which in turn resulted in more controlled prices and more shortages. In January 2013, the Venezuelan Central Bank reported that 78 percent of retail establishments it had surveyed did not have enough sugar, while the figures for other staple shortages were: 67 percent for vegetable oil, 57 percent for corn oil, 86 percent for sunflower oil, 77 percent for wheat flour, and 43 percent for precooked corn. ${ }^{44}$ Over one year, from January 2011 to January 2012 , the price of a kilogram of sugar rose from 87 cents to $\$ 2.56$, while the street price of a bottle of corn oil was over $\$ 4.50$, three times the control price of $\$ 1.40 . .^{45}$ In January 2013, 2.2 monthly salaries at minimum wage were required to buy the monthly food basket. ${ }^{46}$ In addition, food was not necessarily distributed equitably; rather, it was distributed on a clientelistic basis either to neighborhoods that already supported Chávez, ${ }^{47}$ or whose support Chávez hoped to obtain. ${ }^{48}$ Indeed, the Inter-American Commission on Human Rights warned in 2009 that because mission policies appeared to be "determined at the discretion of the executive branch" the impression might be garnered that "some persons are not eligible for these benefits as a result of their political position vis-à-vis the government." ${ }^{\prime 9}$

Some observers maintain that the food missions were used as political tools to persuade people to vote for Chávez in a recall referendum in

41. Javier Corrales \& Carlos Romero, U.S.-Venezuela Relations Since the 1990s : Coping With Mid-Level Security Threats (2013).

42. Mark Weisbrot \& Jake Johnston, Venezuela's Economic Recovery: Is It Sustainable? Center for Economic and Policy Research 21 (2012).

43. Charlie Devereux, Venezuelan Inflation Slows Further as Chavez Eyes Votes, BloOmBerG News, 4 Sep. 2012.

44. DVA Group \& Selinger Group, Venezuelan Daily Brief 9 (18 Jan. 2013), available at http://venezuelandailybrief.blogspot.com/2013/01/caracas-january-18th-2013.html.

45. Fabiola Sanchez, Chavez's Spending Could Boost Venezuelan Inflation, Assoc. Press 3 Jan. 2012.

46. DVA Group \& Selinger Group, supra note 44, 15 Jan.

47. Penfold-Bacerra, supra note 29, at 78-79.

48. Manuel Hidalgo, Hugo Chavez's "Petro-Socialism," 20 J. Democ. 78, 81 (2009).

49. Organization of American States \& Inter-American Commission on Human Rights, Democracy and Human Rights in Venezuela 267 (2009). 
2004, and in the 2006 and 2012 elections: for example, that during the 2006 election the missions allocated resources to "groups whose votes President Chávez sought." ${ }^{50}$ In the run-up to the 2012 election, Chávez imposed controls on a far wider range of goods in an attempt to make sure that the poor could buy them. Despite the shortages, the Mercals remained extremely popular, and Chávez' opponents promised to keep funding them if they won the elections. ${ }^{51}$

Statistics on the right to food in Venezuela showed marked progress from 1999 to 2010. The number of undernourished people fell from an estimated 4 million in 2000 to 1 million in $2010 .^{52}$ In 2000, 27.1 percent of the population was estimated to be without enough food for normal physical activity, but by 2010 that figure had declined to 6.4 percent. ${ }^{53}$ The depth of the food deficit (the number of calories per day per person needed to end malnourishment) fell from 108 in 2000 to sixteen in $2010 .{ }^{54}$ The prevalence of stunting, or child malnutrition, under age five as measured by height per age, was 17.4 percent in 2000 , but had decreased to 15.6 percent by $2007 .{ }^{55}$ The infant mortality rate declined from 19.6 per 1,000 in 1999 to 12.9 per 1,000 in 2011, while the under-five mortality rate declined from 23.1 per 1,000in 1999 to 15.6 in $2011 . .^{56}$

During the first few years of Chávez' tenure the poverty rate rose as a result of a temporary drop in the price of oil and destabilizing political events, including the attempted coup d'état in 2002 and a protracted strike by oil workers in 2002-2003. The percentage of people living below $\$ 1.25$ per day rose from 11.4 in 1999 to 19 in 2003, and the percentage of people living below the national poverty line rose from 48.7 in 1999 to 62 in 2003. Later statistics, however, show a significant drop in poverty, reflecting Chávez' consolidation of power, the recovery in the price of oil, and his creation of social welfare missions. By 2006, the percentage of people living on \$1.25 per day had fallen to 6.6 , while the percentage living under the national poverty rate had fallen to 36 . By 2012 , the national poverty rate had dropped further, to 25.4 percent. ${ }^{57}$ The United Nations Human Development Index $(\mathrm{HDI})$, an aggregate of figures on health, education, and gross national income per capita, also demonstrated improvements in Venezuelans' lives. In

\footnotetext{
50. Myers, supra note 11, at 313.

51. Anne Daguerre, Antipoverty Programmes in Venezuela, 40 J. Soc. PoL'y 835, 843 (2011).

52. Food and Agriculture Organization (FAO), Food Security Indicators VAO1 (2013), available at http://www.fao.org/economic/ess/ess-fs/ess-fadata/en/\#.VZQA40aNq7Q.

53. Id. V15.

54. Id. V14.

55. Id. V16.

56. World Bank, Statistical Database (2013).

57. World Bank Statistical Database (2011), available at http://search.worldbank.org/data?q term $=$ Venezuela + poverty + rate $+\&$ language $=\&$ format $=$.
} 
this index the higher the number the better the standard of living. In 2000 Venezuela's HDI was 0.662 , but by 2012 it was $0.748 .{ }^{58}$

These statistics on food, health, and poverty suggest that Chávez' food policies contributed to better health and reduced poverty. Nevertheless, these policies were not perfect, and in the latter years of Chávez' rule the policies contributed to significant food shortages. Yet it was difficult for Venezuelans to criticize or vote against them, because of Chávez' increasingly authoritarian rule.

\section{CIVIL AND POLITICAL RIGHTS}

Populist claims to represent "the people" do not extend to standard liberal forms of democratic rule. Rather, populist rulers tend to assume that once they win democratic elections they have license to act as they see fit, abjuring legislative checks and balances, undermining the rule of law, and violating those civil and political rights such as freedom of speech and press that might allow their opponents to garner support. This was the pattern in Venezuela under Chávez, who attempted to implement "twenty-first century socialism" to reign in the excesses of "savage capitalism.." ${ }^{19}$ Yet without the protections of civil and political rights mandated by the international human rights regime, citizens opposed to or adversely affected by government policies cannot make their concerns known. This occurred in Venezuela, as Chávez became increasingly dictatorial.

Chávez interpreted his electoral victories as mandates to institute whatever policies he preferred, often ruling by emergency decree. He was determined to carry through his twenty-first century socialism even in the face of evidence that his policies were depriving the very people he wished to help with food. Although he respected the principle of periodic elections, he otherwise developed an increasingly autocratic system of rule. He intimidated or restricted the media, the judiciary, and ordinary voters.

Chávez' many assaults on basic civil and political rights are too numerous to detail in this article; suffice it to say that his philosophy of popular democracy did not include scrupulous attention to the civil and political rights that are normally protected in liberal democracies. After the recall referendum in 2004, a list of 2.5 million people who had signed the petition to recall Chávez was published, thus making known the names of his opponents ${ }^{60}$; some citizens also complained that they had been denied state benefits because they were known to have signed the petition. ${ }^{61}$ During

58. United Nations Development Programme (UNDP) Human Development Report 144 (2013), available at http://hdr.undp.org/en/2013-report.

59. Myers, supra note 11 , at $285,319$.

60. Hidalgo, supra note 48 , at 83.

61. Cristina Marcano \& Alberto Barrera Tyszka, Hugo Chavez: The Definitive Biography of Venezuela's Controversial President 283 (2006). 
the 2006 election, Chávez' supporters used public assets for his campaign and the head of the national oil company, Petróleos de Venezuela (PDVSA) threatened that workers who did not support Chávez would lose their jobs. ${ }^{62}$

On 2 December 2007, a proposal for constitutional amendments which, among other provisions, would have given Chávez the right to be elected president in perpetuity was barely defeated in a referendum. ${ }^{63}$ Chávez was reputed to have expedited citizenship for between 2 and 3 million long-term foreign residents so that they could vote for him. ${ }^{64}$ Chávez won a second referendum to abolish term limits in 2009, in part by implying that those who did not vote for him-especially government employees—would be guilty of treason, and also threatening that civil war might result if he were no longer president. ${ }^{65}$ By law Chávez could requisition television time whenever he wanted for long, rambling speeches, yet his opponents were limited to three minutes of television time per day. ${ }^{66}$ During the 2012 electoral campaign Chávez again threatened a civil war if he did not win. ${ }^{67}$

Chávez also undermined the rule of law and the independence of the judiciary. In 1999, a new constitution was promulgated that enabled Chávez to rule by decree; by the end of 2000 he had issued forty-nine decrees. ${ }^{68}$ In December 2004, the Supreme Court was expanded from twenty to thirtytwo members; this tipped the partisan balance in favor of the government, as the twelve new judges were all Chávez' political allies. ${ }^{69}$

Chávez instituted measures to undermine any interest group that he perceived to be in opposition to his policies. Although he appointed many members or former members of the military to his Cabinet and to various other positions, he also attempted to replace or supplement the military with a private militia that would be personally loyal to him. He did not entirely trust the military after the attempted coup of 2002, ${ }^{70}$ By 2012, there were 125,000 members of this militia, providing an armed counterweight to the ostensibly neutral national military. ${ }^{71}$ Chávez undermined trade union rights, rejecting the principle of an autonomous labor movement and discharging 17,000 people belonging to the oil workers' union after a series of strikes in 2002 to $2003 .{ }^{72}$ In their place, he fostered pro-government workers' coun-

62. Id. at xvii (Moises Naim, Introduction).

63. Myers, supra note 11, at 286.

64. GotT, supra note 6 , at 261.

65. Chavez for Ever? Venezuela's Term-Limits Referendum, Economist, 19 Feb. 2009, available at http://www.economist.com/node/13145105.

66. Henrique and Hugoliath, ECONOmist, 29 Sept. 2012, at 16.

67. Andrew Cawthorne, Venezuela's Chavez Woos Rich, Warns of "Civil War," Reuters, 10 Sept. 2012.

68. Duarte Villa, supra note 8, at 162 .

69. Human Rights Watch (HRW) A Decade Under Chavez: Political Intolerance and Lost Opportunities for Advancing Human Rights in Venezuela 3-4 (2008).

70. Shifter, supra note 15 , at 49.

71. Venezuela's Army: The Vote that Counts, Economist, 11 Aug. 2012, at 32.

72. Myers, supra note 11 , at 306 . 
cils. ${ }^{73}$ As early as 2009, scores of trade unionists were reported murdered and dozens arrested. ${ }^{74}$

In general, Chávez engaged in political discrimination against his real or perceived enemies, denying access to social programs to citizens he perceived as opposing him and blacklisting and firing opponents from the PDVSA and other state-run organizations. ${ }^{75}$ Human rights defenders were intimidated, threatened, and assaulted. ${ }^{76}$ By 2012 there were reports of torture, death threats, and assassinations, as well as politically-motivated charges brought against Chávez' opponents. ${ }^{77}$

Chávez also imposed controls on freedom of the press. He cancelled licenses of opposition television stations, ${ }^{78}$ increased penalties for so-called defamation, and expanded laws of contempt, thus pushing the media to censor itself. ${ }^{79}$ He passed laws permitting the state to supervise the content of the media and permitting imprisonment of any citizen showing "disrespect" to or supposedly insulting government officials. ${ }^{80}$ Judges supportive of Chávez refused to accept decisions critical of the government by the InterAmerican Court of Human Rights ${ }^{81}$ and in 2012 Venezuela withdrew from that court as well as from other human rights organs of the Organization of American States. ${ }^{82}$ These are only a few of the many actions Chávez took that undermined the authority of the legislature, judiciary, and military, as well as the media, trade unions, and civil society groups. Thus, he closed off avenues that might have been able to point out to him how his policies could adversely affect Venezuelans' right to food. They might also have been able to show him how his undermining of the right to own property had adverse effects on the production and distribution of food.

73. HRW, supra note 69 , at 6-7.

74. Socialism v. Labour: Trade Unions in Venezuela, Economist, 9 May 2009, available at http://www.economist.com/node/13611592.

75. HRW, supra note 69, at 2 .

76. International Bar Association Human Rights Institute, Venezuela: Justice under Threat 3 (2007).

77. Amnesty International, (AI) Annual Report 2012: The State of the World's Human Rights, Venezuela 2 (2012).

78. Myers, supra note 11, at 304.

79. Jose Miguel Vivanco \& Daniel Wilkinson, Hugo Chavez Versus Human Rights, 55 N.Y. Rev. Bоокs 68 (6 Nov. 2008).

80. HRW, supra note 69 , at 4 .

81. Allan R. Brewer-Carias, Dismantling Democracy in Venezuela: The Chavez Authoritarian ExperiMENT 140 (2010).

82. Fabiola Sanchez, Venezuela to Pull out of OAS Human Rights Bodies. Assoc. Press, 26 July 2012, available at http://www.thejakartapost.com/news/2012/07/27/venezuela-pullout-oas-human-rights-bodies.html. 


\section{PROPERTY RIGHTS}

From 2000 on, Chávez issued various decrees that "raised doubts about the protection of private property" in Venezuela, ${ }^{83}$ despite the guarantee of the right to property in Article 115 of the 1999 Venezuelan Constitution. ${ }^{84}$ The 2001 Land Law permitted expropriation with compensation of idle, lowquality land from estates that owned a minimum of 5,000 hectares $(12,350$ acres) of such land; in 2005 the amount was reduced to 3,000 hectares. $\left(7,400\right.$ acres) ${ }^{85}$ The law also permitted the government to regulate what was produced on private farms; for example, it could decide that a cattle ranch should produce sorghum. ${ }^{86}$ Chávez had some justification in attempting to redistribute land: in 1997 the bottom 75 percent of Venezuelan landowners possessed only 6 percent of the land, while the top 5 percent possessed 75 percent. $^{87}$

Awash as it was in oil money, the government did promise to compensate former owners of the land at market rates in the local currency, bolivares. ${ }^{88}$ Some foreign landowners, however, wanted compensation in dollars, as consistently high inflation rates devalued the bolivar. Nor did landowners want compensation in government bonds, whose value declined as inflation rose. There were also concerns because the Land Law stated that the government was not obliged to pay landowners for investments they had made in expropriated land. ${ }^{89}$

Exacerbating landowners' concerns, officials began to question the legality of ownership of productive large estates so that they could expropriate them even if they were not idle, ${ }^{90}$ claiming that these properties were actually state-owned. ${ }^{91}$ Indeed, in 2004 Chávez declared a "war on big landowners." ${ }^{\text {"92 }}$ Despite court rulings forbidding it, he encouraged landless Venezuelans to invade large landholdings even before the legality of expropriation had been determined..$^{93}$ The constitutional reform proposals of 2007 contained clauses that would have seriously undermined the right to own property: despite the proposals' defeat Chávez later instituted many of them by decree. ${ }^{94}$ The

83. Kelly \& Palma, supra note 7 , at 225.

84. Const. of Venezuela (1999).

85. Gregory Wilpert, Land for People Not for Profit in Venezuela, in Promised Land: Competing Visions of Agrarian Reform 249, 254 (Peter Rosset, Raj Patel, \& Michael Courville eds., 2006).

86. MARCANO \& TSZYKA, supra note 61 , at 146-47.

87. Wilpert, supra note 85 , at 252.

88. Id. at 254 .

89. Id. at 256 .

90. Id. at 259; Jones supra note 6, at 438-39.

91. Javier Corrales, Hugo Boss, 152 ForelGn PoL'y 32, 37, 19 Oct. 2009, available at http:// foreignpolicy.com/2009/10/19/hugo-boss/.

92. Chavez to Nationalize More Land in Venezuela, Latin Am. Tribune, 12 Oct. 2010.

93. Wilpert, supra note 85 , at 256.

94. BREWER-CARIAS, supra note 81 , at 317 . 
result was many occupations and takeovers of property, including of large estates previously protected as long as their land was not idle. Thus, many of these "rescued" lands were not paid for, as they were considered to have been left idle or not legally acquired in the first place. ${ }^{95}$

The frequently extra-legal and arbitrary expropriations caused chaos in the commercial farming and ranching sectors. As early as 2001 the Venezuelan Cattle Ranchers Association reported that 139 farms had been invaded, although the government claimed the figure was an exaggeration. ${ }^{96}$ By 2010 , the government had reportedly seized between 5 million ${ }^{97}$ and 7.5 million acres of farmland ${ }^{98}$ out of a total of about 67 million acres considered suitable for cultivation, ${ }^{99}$ or 7.5 to 11 percent of Venezuela's total cultivable land. In late 2011, the Venezuelan Supreme Court ruled that it was not necessary to enforce the criminal code against people occupying private land, arguing that "above private rights are those rights for the common good destined to the production of food or other products for human consumption."100

Yet it does not appear that redistribution of land to small farmers increased the food supply. Any Venezuelan head of household or young person could apply for land, seemingly regardless of whether he or she was an experienced farmer. ${ }^{101}$ But government assistance was disorganized and the new peasants often had trouble getting credit to buy seed. ${ }^{102}$ The result appears to have been a severe drop in the absolute amount of food produced in Venezuela. Carlos Machado, an agricultural expert, calculated that from 2004 to 2012 rice production fell by 34 percent, cattle production by 27 percent, and maize production by 25 percent. ${ }^{103}$ Reliance on imported food rose from 64 percent of food in 1998, ${ }^{104}$ to 75 percent in 2005, ${ }^{105}$ and to 90 percent in 2012. Another agricultural expert, Alejandro Gutierrez, noted that during the period 2003 to 2011 Venezuela imported agricultural products in which it had previously been self-sufficient, such as beef, rice, and maize, while its food exports declined by 93 percent from 1998 to $2011 .{ }^{106}$

95. Juan Paullier, Lo que se Sabe de las Expropiaciones de Chavez, BBC Mundo, 2 Jan. 2012.

96. Back to the Soil, Economist, 26 Apr. 2001.

97. Ian James, Farmer-Turned-Hunger Striker Dies in Venezuela, Assoc. Press, 31 Aug. 2010.

98. PROVEA.Informe Anual Octobre 2010-Septiembre 2011, Derecha a la Tierra (2012), available at http://www.derechos.org.ve/pw/wp-content/uploads/11Tierras2.pdf. [PROVEA [NATIONAL Program on Human Rights Education and Action] Annual Report October 2010-September 2011. Right to Land].

99. Id.

100. Venezuelan Supreme Court Endorses Land Grabbing Alleging the Right to Food, MerCoPress, 17 Dec. 2011.

101. Wilpert, supra note 85 , at 255.

102. Id. at 261-62.

103. Sara Schaefer Munoz, Key Issue in Venezuelan Vote: Food, WSJ.com, 10 Apr. 2013.

104. Gotr, supra note 6, at 164.

105. Wilpert, supra note 85, at 262.

106. Alejandro Gutierrez, El Sistema Alimentario Venezolano A Comienzos Del Siglo XXI: Evolucion, Balance y Desafios, 2013. 
Aside from weather problems, public policy measures that caused this decline in productivity were insecurity of land tenure and fear of expropriation; lack of investment in infrastructure; scarcity of inputs; and lower prices paid to producers. ${ }^{107}$ Yet figures from the Food and Agriculture Organization (FAO), comparing 2011 to 1999 show increased production in such staples as milk, rice, maize, and chicken. ${ }^{108}$ These FAO figures, however, might have resulted from use of unreliable figures produced by the national Venezuelan government, figures which might have been deliberately rigged, especially by over-calculating production on expropriated land. ${ }^{109}$

Chávez not only attacked the property rights of landowners and other food producers, he also attacked the property rights of wholesale and retail distributors. During the early years of his rule, he was able to use Venezuela's enormous oil earnings to provide state-subsidized food to the poor. However, the unpredictable nature of these earnings meant that he was not always able to subsidize food as much as he wished. Chávez then began to blame the market economy, claiming that price-gougers and hoarders were responsible for the high price of food. Increasingly, he used the slogan "exprópiese!" ("expropriate it"), proposing that expropriations would release food supplies and lower their price.

By 2010, Chávez had nationalized almost 400 businesses, although these were not only in food ${ }^{110}$; many of these nationalized industries underutilized their capacity, went into debt, and produced less than they had under private owners. ${ }^{111}$ For example, the government owned half of the productive capacity of pre-cooked maize flour but supplied only a fifth of the market ${ }^{112}$; pre-cooked maize flour is the central ingredient of Venezuela's staple food, the arepa. Although he had promised to pay market prices for nationalized industries, Chávez began to renege on these promises as his expenditures on other parts of the economy outstripped his revenues from oil.

Faced with price controls and threats to imprison those who violated them, ${ }^{113}$ private businesspeople withdrew from food production and distribution, as they could not afford to produce or sell at the prices Chávez had decreed. In early 2010, Chávez closed down hundreds of stores for "speculation," and seized a French supermarket chain. ${ }^{114}$ In May 2010, forty

107. Id. 26-28.

108. FAO Stat, Commodities by Country, (sorted for Venezuela, 1999 and 2011), available at http://faostat.fao.org/site/339/default.aspx.

109. Alejandro Gutierrez, Telephone Conversation with Antulio Rosales on Venezuelan Food Statistics, Waterloo, Ontario, 28 Dec. 2013.

110. Corrales, A Setback for Chavez, supra note 28, at 125.

111. Imports Feed Consumption in Venezuela, El UnIVERSAL, 1 Nov. 2012 [trans. Andreina Trujillo].

112. Venezuela's Economy: Out of Stock, Economist, 9 Feb. 2013.

113. Simon Romero, Chavez Threatens to Jail Price Control Violators, N.Y. TImEs, 17 Feb. 2007.

114. Venezuela's Drift to Authoritarianism: Wolf Sheds Fleece, Economist, 28 Jan. 2010, available at http://www.economist.com/node/15393502. 
butchers were detained and some strip-searched on the grounds that they were driving up beef prices; the result was that many butchers stopped selling beef entirely. ${ }^{115}$ In 2012, dairy products and coffee, both produced on farms that had been nationalized, were in extremely short supply: Venezuela had even begun importing coffee, which it had exported until 2009. ${ }^{116}$ High inflation rates raised the costs of inputs for food producers, yet price controls meant that they could not raise the prices at which they sold, driving some producers out of business.

Unsurprisingly, the government had to spend more money on food imports as the local food supply shrank. Nor did the state properly manage these imports: in June 2010, the government admitted that 30,000 tons of food was rotting on the docks, although opposition media claimed the figure was 75,000 tons. ${ }^{117}$ In January 2013, it was reported that imported goods were delayed for an average of forty-five days at the docks before they could be distributed; this might have been in part because many of the general managers at the ports were members of the military, ${ }^{118}$ some of whom demanded bribes before they would release the food. Another reason for delays was corruption on the part of importers in cooperation with those who managed the ports; the longer the delays, the more they could demand more foreign currency to import and sell more items. ${ }^{119}$ Delays, wastage, and sale of controlled food on the black market might help explain why, for example, from 2006 to 2012, grain imports from neighboring Latin American countries increased by 375 percent. ${ }^{120}$ Yet the government's response to shortages was often to blame private producers for hoarding (which some may have done) rather than to rectify inefficiencies in production, storage, and transportation of food, inefficiencies sometime caused by corruption or the granting of monopolies.

\section{MACRO-ECONOMIC POLICIES: UNDERMINING FOOD SECURITY}

The statistical data above on reduced rates of malnutrition and undernourishment suggest improved distribution of food to the poor at least during

115. Fabiola Sanchez, Butchers Beware: Venezuela Cracks Down on Prices, Assoc. Press, 7 May 2010, available at http://www.boston.com/business/articles/2010/05/07/butchers_beware_venezuela_cracks_down_on_prices/.

116. William Neuman, With Venezuelan Food Shortages, Some Blame Price Controls, N.Y. Times, 20 Apr. 2012.

117. Venezuelan Socialism: Food Fight, Economist, 10 June 2010, available at http://www. economist.com/node/16326418

118. DVA Group \& Selinger Group (22 Jan. 2013), supra note 44, at 6.

119. Antonio Maria Delgado, Wikileaks Report Cites Corruption in Venezuelan Production, Miami Herald, 7 Mar. 2012.

120. Imports Feed Consumption in Venezuela, supra note 111. 
the first few years of Chávez' rule, despite his undermining of the property rights of those who produced and sold it. Thus at least in the short term, Chávez' populist policies were successful in fulfilling Venezuelans' right to food. This also suggests that violations of civil and political rights do not necessarily mean concomitant violation of economic human rights, at least in the short term. Redistributive (quasi) socialist policies can be implemented without civil and political liberties.

However, such short-term improvements in the human right to food undermined Venezuelans' longer-term food security. Chávez relied heavily on earnings from Venezuela's oil exports to subsidize imports of food, as internal production and distribution declined. If Chávez mismanaged possibly temporary profits from the oil economy, then the investments necessary to sustain Venezuela's economy-including its long-term food security-might be at risk. Even if the profits were not temporary and oil retained its high price over the long term, mismanagement of other aspects of the economy could undermine the usefulness of oil rents.

Chávez used profits from the state-owned oil company, PDVSA, which had been nationalized in 1976 by an earlier government, to finance food imports as well as his health, education and food missions. As of 2002, the PDVSA was required to release at least 10 percent of its annual investment for social spending ${ }^{121}$; for example, in 2006 , it was responsible for $\$ 13.3$ billion in social spending, or 7.3 percent of GDP. ${ }^{122}$ In 2012, it donated $\$ 15.5$ billion directly to the National Development Fund (Fondo de desarollo nacional: FONDEN) and spent another $\$ 28$ billion on social development, adding up to about a quarter of its reported earnings. ${ }^{123}$ Such spending might be justified if use of oil funds did not cause underinvestment in the oil company, but money that might have been used to pay PDVSA employees, to maintain its equipment, and for reinvestment was instead diverted to social projects.

The state takeover of the PDVSA resulted in some inefficiency and mismanagement, as Chávez often appointed military officers, his own family members and his political supporters to take charge of PDVSA and of other important economic assets, regardless of whether they were qualified for their positions. The PDVSA suffered from loss of technical capacity and the problem of having to satisfy a "growing web of political patronage." ${ }^{124}$ By 2013 PDVSA had cut its production from a planned 5.8 million barrels per day to between 2.8 and 3 million barrels. ${ }^{125}$ An explosion at an important refinery in August 2012, killing at least forty-two people, showed how the PDVSA was deteriorating. ${ }^{126}$

121. Goтt, supra note 6, at 312 .

122. Weisbrot \& Sandoval, supra note 32, at 9.

123. Petroleos de Venezuela S.A., Informe de Gestion Annual (Annual Business Report) (2012).

124. Rodriguez, supra note 37.

125. Venezuela's Economy, supra note 112.

126. Venezuela's Refinery Disaster: A Tragedy Foretold, Economist, 1 Sep. 2012. 
Chávez appeared to regard Venezuelan oil as a personal asset that he could use as he saw fit to promote his policies and political agenda. He sold 1 million barrels of oil a day at subsidized prices either in Venezuela or to allied countries. ${ }^{127}$ This was not necessarily a sound economic decision, as he could have sold the subsidized oil at higher prices on the international market and used the profits to invest in Venezuela's future. In 2012 the price of oil for Venezuelans was only 1.6 cents a liter, ${ }^{128}$ yet this was partly a subsidy to wealthier Venezuelans, who were far more likely to own cars than the poor.

Chávez also used oil to help like-minded Latin American states. He sent 90,000 barrels per day to Cuba in return for 30,000 doctors and other specialists. ${ }^{129}$ Jamaica, the Dominican Republic, and ten other Caribbean states signed an accord with Venezuela in 2005 allowing them to pay 40 percent of their oil debts over twenty-five years in either cash or food such as bananas, sugar, or rice. ${ }^{130}$ Oil from Venezuela also helped support Nicaragua, one of the poorest countries in the Americas and one in which the business and investment communities were still treated with suspicion. ${ }^{131}$ Indeed, through the PDVSA-owned American retailer, CITGO, Chávez even supplied cheap fuel to several poverty-stricken areas in the United States, undoubtedly to point out the iniquity of poverty in his imperialist enemy ${ }^{132}$ : this generous subsidy to Americans was stopped in 2009 when the Venezuelan economy began to unravel. ${ }^{133}$ The provision of oil that was almost free to Venezuelans and at very cheap prices to political allies, combined with reduced production at PDVSA because of mismanagement, meant that by 2013 Venezuela faced a hard currency shortage and could not import enough food..$^{134}$

Much of the money that Chávez requisitioned from PDVSA was invested in FONDEN, an agency that he used to finance his missions. At least during the early years of his tenure, Chávez personally controlled FONDEN, rather than allocating its funds to the various ministries in charge of social services, creating, as it were, a "parallel state."135 Neither professional bureaucrats nor anyone else knew exactly how Chávez spent FONDEN's monies; FONDEN was unaudited and disbursal of its funds not subject to normal oversight or

127. Venezuela's Economy: Oil Leak, Economist, 24 Feb. 2011, available at http://www. economist.com/node/18233412.

128. Venezuela's Oil Exports to US Decline, Reflecting Downward Trend During Chavez Government, Assoc. Press, 2 Feb. 2012, available at http://finance.yahoo.com/news/ venezuelas-oil-exports-us-decline-150038661.html.

129. Max Azieri, The Castro-Chavez Alliance, 36 Latin Am. Perspectives 99, 100 (2009).

130. Steve Ellner, Toward a "Multipolar World": Using Oil Diplomacy to Sever Venezuela's Dependence, 40 NAClA Rep. on the Americas 15, 16 (2007).

131. Stephen Kinzer, Life Under the Ortegas, 55 N.Y. Rev. Of Books, 12 June 2008, at 60.

132. MarCANO \& TYSZKa, supra note 61 , at 311, n. 17 .

133. An (Iron) Fistful of Help: Development aid From Authoritarian Regimes, Economist, 6 June, 2009, at 59.

134. Moises Naim, Chavez Will Leave Behind an Economic Crisis. N.Y. TImes, 8 Jan. 2013.

135. MarCano \& TYSZKa, supra note 61, at 269. 
decision making. ${ }^{136}$ Neither the criteria for citizens' access to benefits nor the rules for allocation of resources were clear. ${ }^{137}$ It was also not possible to ascertain whether later on transparent or accountable budgeting procedures were instituted for the missions: the government was "reluctant" to release information on mission programs, including the food mission. ${ }^{138}$

Control of FONDEN was the reason that Chávez could announce grandiose projects, many of which would then lie dormant or incomplete. Between 2005 and the end of 2012, FONDEN received \$56.9 billion from the PDVSA and another $\$ 45.3$ billion from the Central Bank, ${ }^{139}$ enormous amounts which were under Chávez' personal control. The "off -balancesheet spending ${ }^{\prime 140}$ enabled Chávez to distribute food and other goods to his supporters and withhold it from his opponents and detractors. Despite his control of FONDEN, however, Chávez still did not have enough money to finance the missions, and he began to look for new sources of funds in the later years of his presidency. Starting around 2008, he began to borrow funds from China in exchange for oil at low prices. By 2013, these loans were in the range of $\$ 46.5$ billion over the preceding four years. ${ }^{141}$

Chávez also increased the number of people employed by the state, thus removing some people from poverty while also ensuring his own popular support. By 2009, public sector employment had doubled to 2 million people. ${ }^{142}$ This is a standard populist measure that can become economically unsustainable in the longer term and was only sustainable in Venezuela because of the country's oil wealth. Some of these new jobs were given to people who were not competent to do their duties, as in the case of political or patronage appointments to the PDVSA.

Whatever Chávez' attempts to improve access to food were, they were undermined by extremely high levels of inflation during the second half of his rule. This inflation was caused in part by devaluation of the bolivar. During the first few years of Chávez' tenure, the bolivar was overvalued relative to foreign currencies. This encouraged imports of food that would have been more expensive if the bolivar had not been over-valued; indeed, it was often cheaper to import food than to produce it locally, discouraging local production. ${ }^{143}$ This over-valued currency permitted imports of protein-rich foods such as chicken, improving Venezuelans' diet during this period, even

136. Javier Corrales \& Michael Penfold, Dragon in the Tropics: Hugo Chavez and the Political Economy of Revolution in Venezuela 57-59 (2011).

137. OAS, Inter-Aм. Сомm. Hum. Rts., supra note 49, at 266-67.

138. Penfold-Becerra, supra note 29, at 75.

139. DVA Group \& Selinger Group, supra note 44.

140. Penfold-Becerra, supra note 29, at 75.

141. DVA Group \& Selinger Group (18 Jan. 2013), supra note 44.

142. Socialism with Cheap Oil: Venezuela, EConomist, 30 Dec. 2008, available at http://www. economist.com/node/12853975.

143. Corrales, supra note 27 , at 126. 
though domestic food production simultaneously declined. ${ }^{144}$ From 2003 on, however, the government devalued the bolivar five times. ${ }^{145}$ Imported food was now more expensive, so less was brought in; this was exacerbated by the requirement that importers apply for allocations of foreign exchange from the government, some food importers having to wait three to six months for import permits. ${ }^{146}$ Company managers would queue for days hoping to receive a foreign exchange allocation, then give up and reduce imports. ${ }^{147}$

At the same time, the changes in property relations discussed above meant that less food was being distributed internally. The result was the classic definition of inflation, "too much money chasing too few goods;" in this case, the scarce goods included food. The food price level index, an index of the price of food relative to the price of a generic consumption basket in the US in 2011, rose from 2.15 in 2000 to 4.06 in 2013. ${ }^{148}$ Chávez tried to encourage more food imports by introducing dual exchange rates for essential (food) and non-essential goods; for example, to buy essential goods in May 2010 one dollar cost 2.6 bolivars, whereas for non-essential goods one dollar cost 4.3 bolivars. ${ }^{149}$ The official rate rose to 6.3 bolivars per dollar in February 2012 for essential goods, and a higher rate for nonessential transactions. ${ }^{150}$ These dual exchange rates facilitated currency manipulation, as some private businesses used the opportunity to import food at the lower exchange rate and then sell as if they had imported at the higher exchange rate.

In an attempt to counteract inflation during the run-up to the 2012 elections, Chávez announced controls on almost 100 new food and other essential products. However, because both food imports and internal distribution had been reduced, the one because of devaluation and the other because of expropriations and price controls, the sporadic food shortages that had been occurring since 2007 became quite severe. Between 2007 and 2013, more and more shops offered fewer and fewer goods for sale. While the cost in money of controlled foods might have been very low, the cost in time to obtain food was severe as consumers spent long hours in lines searching for food at different Mercals in their neighborhoods.

144. Jose Enrique Rodriguez Rojas, Evolucion de la Dependencia Externa Proteinica y Sus Determinantes Macroeconomicos en el Periodo 1989-2006, 15 Revista Venezolana de Economia y Ciencias Sociales 37, 49 (2009) [trans. Antulio Rosales]. (Evolution of Dependence on External Proteins and its Macroeconomic Determinants in the Period 1989-2006, J. Venezuelan Econ. \& Soc. Sci.).

145. Javier Corrales, The House That Chavez Built, ForelGn Pol'y (2013), available at http:// foreignpolicy.com/2013/03/07/the-house-that-chavez-built/.

146. DVA Group \& Selinger Group (25 Jan. 2013), supra note 44, at 1.

147. Corina Rodriguez Pons \& Daniel Cancel, Chavez's Currency Market Takeover Spurs Lines for Dollars, BLOOMBerG, 21 Feb. 2011.

148. FAO, Food Security Indicators, available at http://www.fao.org/economic/ess/ess-fs/ ess-fadata/en/\#.VglmdE2FPct.

149. Frank Jack Daniel, Chavez Signs New Currency Law against Speculation, Reuters, 16 May 2010.

150. The Party is Over, Economist, 1 Feb. 2014, at 27, 28. 
Finally, corruption contributed to economic mismanagement. Chávez' personalist and nepotistic governing style meant that he appointed family members, friends from his days in the military, and political allies not only to senior positions in government but also to senior management jobs in the industries that he nationalized, as well as in the previously-nationalized PDVSA. Corruption and nepotism resulted in mismanagement and underproduction, which resulted in fewer exports and fewer dollar earnings that could be used to buy food: underproduction at food-producing and processing facilities also resulted in less food both for the Mercals and the open markets. As an example of nepotism, one banker originally close to Chávez was granted a monopoly to supply staple foods to the Mercals, thus presumably charging more than would have been the price had there been some competition among suppliers. ${ }^{151}$ Transparency International, an anticorruption NGO, consistently ranked Venezuela as one of the most corrupt nations in the world. In 2013, it was ranked 160th of 177 countries: in this corruption perception index, the higher the number, the more corrupt the country is perceived to be. ${ }^{152}$ Even if individual appointees were not corrupt, their incompetence adversely affected the food supply.

\section{CHÁVEZ: AN INCOMPETENT STEWARD OF THE RIGHT TO FOOD}

If one looks at the three aspects of the right to food, to respect, protect, and fulfill it, then Chávez' record is mixed. He did respect the right to food, which was originally one of his top priorities. He attempted to fulfill citizens' right to food by instituting Mercals, free food distribution, school feeding programs, and price controls. Moreover, whatever their defects, his policies may have two positive long-run effects. Economically, his health, education, and food distribution policies might have improved Venezuela's human capital, as his Ambassador to the US noted in 2006: "Although some critics have called these programs [the missions] clientelistic, they are simply responding to long-ignored needs and building much-needed human capital in Venezuela." 153 For example, programs providing school meals meant that children would be better able to learn: this may have long-run positive effects if and when Venezuela returns to a more orthodox market economy. Politically, Chávez made it difficult for future leaders to ignore the poor.

Nevertheless, Chávez' short-term fulfillment of nutritional needs came at the expense of citizens' longer-term food security; in effect, he did not protect the right to food. In a 2004 speech at the United Nations, Chávez

151. Fall of the Boligarchs: Banking in Venezuela, Economist, 12 Dec. 2009.

152. Transparency International, Corruption Perceptions Index (2013).

153. Bernardo Alvarez Herrera, A Benign Revolution: In Defense of Hugo Chavez, 85 Foreign AfF. 195, 198 (2006). 
spoke of food security as a goal of his Bolivarian revolution, ${ }^{154}$ yet far from increasing the amount of food available, nationalizations and price controls undermined food production and distribution. The inflationary pressures caused by economic mismanagement priced much food out of reach of ordinary Venezuelans, while mismanagement at the ports meant imported food was delayed and sometimes rotted. Expropriation and redistribution of land resulted in a decline in food production. Under-pricing and bartering of oil rather than selling it on the world market undermined Venezuela's long-term capacity to protect the right to food because fewer funds were available for imports. And the clientelistic distribution of food to supporters over opponents meant that individual food security became a relatively scarce political good.

Chávez was an incompetent steward of his country's economic future, wasting oil resources, expropriating food producers without planning how to replace them, and driving food distributors out of business by imposing unrealistic price controls. Venezuela would have been better off had Chávez respected property rights and the market while continuing to subsidize food for those who needed it. But statistics do not indicate that in the short run the people of Venezuela suffered severely from food shortages; certainly, there were no reports of starvation or of severely high rates of malnutrition. Moreover, many of the errors in planning, management, and distribution that Chávez made had also been made by preceding regimes that relied heavily on oil revenue, suffered from high inflation rates, and instituted price controls. ${ }^{155}$ Chávez is distinguished mainly by his focus on the poor (albeit more on his perceived supporters among the poor) and by his attack on private property. The former is laudable: the latter economically unwise.

Chávez' populist platform was to provide resources for the poor-including food-to which they had previously not had access. Yet he sacrificed the long-term economic health of Venezuela and with it long term food security, to achieve his short-term goals. The support he received in the 2012 elections, despite food shortages, was in part because many people believed that he cared about them in a way that his predecessors had not. The fact that before that election the opposition had to assure voters that they would continue the missions-albeit with more efficiency and accountability - may indicate that politics in Venezuela had changed for the better for the long run. ${ }^{156}$

On the other hand, Venezuelans continued to face food shortages after Chávez' death as his successor, Nicolás Maduro, continued his policies,

154. Terry Gibbs, Business as Usual: What the Chavez Era Tells Us about Democracy Under Globalisation, 27 THIRD WORLD Q. 265, 270 (2006).

155. Daguerre, supra note 52, at 835.

156. Andrew Cawthorne, Chavez Says Foes Would Harm Slums, see off Cubans, Reuters, 7 Nov. 2011. 
imposing price controls on fifty more items in early $2013 . .^{157}$ The twelvemonth inflation rate skyrocketed to 35 percent per year by June $2013,{ }^{158}$ while the price of food rose by 72.1 percent between October 2012 and October 2013,159 partly as a result of continued devaluation of the bolivar but also as a result of food scarcities. Rice, coffee, and beef, previously produced inside the country, now arrived from other countries. ${ }^{160}$ Maduro spent much of his time making deals with other Latin American countries to import food from them, but this food often rotted as ships could not unload at congested, inefficiently-run ports. ${ }^{161}$

Spontaneous technological inventions arose among the population to help people find food. Mobile apps were developed to provide information about what goods were available where, ${ }^{162}$ while a website was developed to provide information about the real (black-market), as opposed to the official exchange rate: Maduro responded by ordering the arrest of the individuals maintaining the exchange-rate website. ${ }^{163}$ When not blaming the shortages on an imperialist, CIA-led conspiracy, Maduro explained them away by focusing on "over-consumption" by Venezuelans. ${ }^{164} \mathrm{He}$ also blamed shortages on a deliberate campaign of sabotage by food producers and distributors, ordering government agents to "raid" private companies' warehouses for allegedly hoarded food. The private producers responded that much of the hoarded food was simply what was needed to produce finished goods. Difficulties in obtaining government permission to buy dollars also meant that the largest food company in Venezuela, Empresas Polar, could not import enough inputs for processed food such as the pre-cooked flour for arepas. ${ }^{165}$ Meanwhile, smugglers were selling price-controlled food over the border in Colombia, exacerbating the food shortages. ${ }^{166}$

Ironically, just as food shortages worsened, Maduro accepted an award from the FAO for Venezuela's success in reducing malnutrition. ${ }^{167}$ While this

157. Corrales, supra note 146.

158. Venezuela Inflation Rises to 35\%, Latin Am. herald TRIB., 18 June 2013.

159. Victor Salmeron, Inflacion de Alimentos en Venezuela es la mas Elevada de America Latina, El Universal, 12 Dec. 2013.

160. James Anderson, In Venezuelan Election, Food is a Voting Issue, Assoc. Press, 10 Apr. 2013.

161. Cargo Ships With 353 Tons of Food Stuck in Puerto Cabello, Venezuela, El UnIVersal, 19 Sept. 2013.

162. Finding Scarce Food and Toilet Paper in Venezuela-Now There's A Free Mobile App For That, Assoc. Press, 9 June 2013.

163. Antonio Maria Delgado, Venezuela Interim President Maduro Takes on Currency Exchange Website, Miamı Herald, 26 Mar. 2013.

164. Maduro Estimates Overconsumption at 30\%, EL UnIVERSAL, 12 June 2013.

165. Andrew Cawthorne, Venezuela's Polar Issues Sharp Response to Maduro, ReuteRs, 5 Apr. 2013.

166. Jorge Rueda \& Frank Bajak, Food Rationing to Begin in Big Venezuelan State, Assoc. PRESS, 4 June 2013.

167. FAO to Support Venezuela Against Food Shortage, El Universal, 17 June 2013. 
success was real, it was due in large part to Venezuela's oil revenues and to general and unsustainable mismanagement of the economy. If Venezuelan mothers could not find milk for their children, as was happening in 2014, then malnutrition could rise in the not-so-distant future. Indeed, in early August 2013 forecasters were predicting a long-term decline in food consumption by 7.5 percent by $2017 . .^{168}$ In 2013 the cost of food rose by 74 percent. ${ }^{169}$ Maduro's insistent continuation of Chávez' economic policies did not bode well for Venezuelans' future human right to food. In early 2014, there were large anti-Maduro demonstrations in the streets of Caracas protesting food shortages among other problems, and three people had been killed. ${ }^{170}$

168. New Market Research Report: Venezuela Food \& Drink Report Q3 2013, Small Bus. Newswire, 12 Aug. 2013.

169. Food prices in Venezuela the Highest in 18 Years, El UniverSAL, 27 Jan. 2014.

170. Ezequiel Minaya \& Juan Forero, Leader of Protests in Venezuela Turns Himself in, WALL St. J., 19 Feb. 2014, available at http://www.wsj.com/articles/SB100014240527023048 99704579391091260822438. 